\title{
Choosing a camera for mine surveying of mining enterprise facilities using unmanned aerial vehicles
}

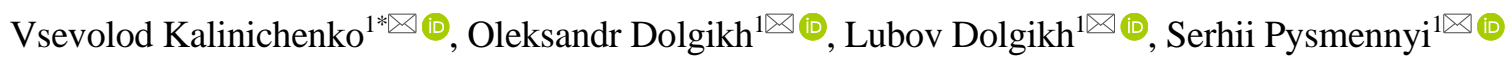 \\ ${ }^{1}$ Kryvyi Rih National University, Kryvyi Rih, 50027, Ukraine \\ *Corresponding author: e-mail dlavgeod@gmail.com, tel. +380973931157
}

\begin{abstract}
Purpose. Choosing an effective method for performing the mine surveying of the objects at mining enterprise based on the implementation of practical and analytical work. Particular attention is focused on the use of modern technologies for performing field and cameral work, which, in turn, enable to determine the most effective tools and methods for per-forming survey work in open pits, dumps, in collapse zones, and the like. At the same time, one of the priorities when creating graphic material in the form of a mine surveying plan or other mining-graphic documentation is strict compliance with the requirements for the quality of the drawn up documents.
\end{abstract}

Methods. Analysis of the experimental data obtained as a result of the survey work: the mine territory, where the earth's surface collapsed; open pit flank where displacement is observed; open pit area, where reclamation is conducted. The photographic survey from the ground and from the air is made with digital cameras with different specifications for matrices and lenses. When surveying from the ground, photography from a tripod is used, and when surveying from the air, the camera is carried by an unmanned aerial vehicle.

Findings. The qualitative characteristics of the images have been obtained, created by different cameras in various photographic survey conditions. The dependence of the accuracy in determining the points coordinates from the digital images on the quality characteristics of the survey equipment has been obtained, which is used when photographing from the ground or installed on unmanned aerial vehicle.

Originality. Patterns have been obtained between the accuracy of the data, measured from the research object images, and the metric characteristics of digital cameras and lenses that are used to obtain them.

Practical implications. A method has been developed for performing highly efficient photographic surveys of open pits, dumps and other facilities of mining enterprises. Practical data have been obtained and analysed for the use of various types of cameras and lenses to them. The analysis of the measurement characteristics of the images makes it possible to conclude that further research in this direction is necessary in order to improve the existing methods for performing ground and air photography of open pits and other objects of mining enterprises.

Keywords: images, collapse zone, camera, lens, matrix

\section{Introduction}

It is known that at present, modern digital survey methods are used to solve many problems of mine surveying service at mining enterprise. Digital survey methods make possible to solve a wide range of tasks from drawing up a mine surveying plan to determining the volume of mining operations, designing works, etc. These methods are especially effective when monitoring for the deformations of the earth's surface and objects located on it [1]-[4]. Small aircraft have been used for several years in photographic survey when mapping territories [5]. In the last two or three years, unmanned aerial vehicles (UAV), which are more mobile and cheaper to maintain, are increasingly used for survey work in geodesy and mine surveying.
Photo and video recording is made from unmanned aerial vehicles using special equipment, for the successful operation of which navigation devices are used [6].

The images quality depends on the quality of the used optics, which is characterized by the value of distortion. Many scientific works are devoted to the problems of improving image quality. It is known that image quality is significantly influenced by deformation caused by distortion of camera lens, therefore, in some works, methods to reduce this influence are considered [7]-[9]. An effective method of combining (stitching) images is proposed when making plans for the area of surveying. An important issue is also to obtain highquality cartographic material which is created on the basis of surveying results using digital cameras set on unmanned aerial vehicles. The software that is supplied to the UAV, as 
a rule, does not take into account that the plans and maps must meet the requirements imposed on them by the corresponding instructions [10], [11].

The process of aerial photography is an important component of aerial surveying, which allows to improve the quality of geodetic and mine survey works, to provide automated surveying. Aerial photography enables mapping of terrain areas that are dangerous for a human presence on them.

Many works are aimed at performing underground mining of mineral deposits with the use of various mining systems and technological methods that increase the stability of underground mining objects [12]-[14]. The task of monitoring for the displacement zones remains relevant and requires the use of more effective methods of their research [15]-[20].

Mine surveying is an exact, mathematical science, but it is worth remembering that at the beginning of the $20^{\text {th }}$ century, mining geodesy was called as "Markscheidekunst". In addition, one should recall the words of the American philosopher and poet George Santayana that those who do not remember their past are condemned to relive it. It is therefore quite clear that the mine surveying plan should be more than just a set of redundant data, but a work of art. In what way this can be achieved - using modern technologies or traditional methods - there is no answer to this question yet.

Having analyzed the development of modern computer technologies and the theory of "image recognition", it can be concluded that in the next decade they will not be able to surpass the capabilities of an engineer-mine surveyor, who with high accuracy can determine the abutment of lines and points of edges, roads and other structural elements of the plan. As a result, there is an understandable document that is easy to read - survey plan of mining operations. It is obvious that by replacing a mine surveyor at mining enterprise with a specialist who only calculates the volume of mining operations, it is possible to do with the automatic construction of a digital model. This approach is incorrect, as it leads to the degradation of the specialty. A craftsperson would be able to calculate the volume of mining operations, but only an engineer-mine surveyor is capable to competently solve many other problems related to the designing and planning of mining operations, rational mining of minerals, ensuring the safety of mining operations and other tasks.

The question of choosing a method and technique for performing survey work is also relevant [21]-[23]. The choice has to be made between the modern possibilities of surveying technology, namely, the use of wide-angle cameras with short-focal lenses.

During the era of analog photogrammetry, when cameras with focal distances of $100-250 \mathrm{~mm}$ and a frame size of $180 \times 180 \mathrm{~mm}$ or $250 \times 250 \mathrm{~mm}$ were used, there was no possibility of automatic correction for distortion, but their manufacturers guaranteed minimal deformations due to distortion. Recently, cameras with a focal distance of $35 \mathrm{~mm}$ have been used, however, lenses with a focal distance of 50-52 $\mathrm{mm}$ are more effective, since they give an ability to obtain an image of a larger scale with a higher resolution. The development of photogrammetric image processing has made it possible to automatically correct distortion, which is used by leading manufacturers of drones used for topographic surveys.

When using UAV, as a rule, cameras with small focal distance are used, because these small aircraft cannot lift a heavy camera and fly with it for some time.
When using UAV for surveying of mining enterprises, it is important to choose a method for photogrammetric processing of digital images by means of appropriate software [24], [25]. At present, when using UAV, the issues that need to be improved are: increasing the accuracy of determining the position of points from images, when monitoring for deformations; improving the quality of mine surveying plans, which would meet the instruction requirements for the production of mine survey works. This is the purpose of this research.

\section{Methods}

It is known that as a result of processing aerial survey materials obtained with the use of UAV and the software supplied to it, various materials can be obtained: orthophotoplan, point cloud, digital terrain model (DTM) or tile model [26]. However, the mine surveying plan, profile or other mining-graphic document obtained as a result of such a surveying does not comply with the requirements of special instructions and manuals.

It is widely believed that it is possible to replace the horizon-oriented plans, sections, topographic surface plans imaging the positions of the upper and lower edges, points with characteristic symbols, other structural elements with a point cloud or orthophotoplan connected to the horizontals. This paper studies the question of the possibility of such claims and feasibility of such changes. The probability and quality of the data obtained as a result of such a survey is studied for solving various problems of mine surveying service at mining enterprise.

One of the main advantages of a mine surveying plan is its "readability". Earlier, when there were no modern tools of computer visualization, this concept suggested quick and understandable presenting the topographic information in a form that is convenient for visual perception and analysis. With the current computer technology, the term "visualization" is widespread in mine surveying, which implies the specific capabilities of software products aimed at presenting 3D data (for example, a point cloud) in the form convenient for visual perception.

From the above facts it is clear that earlier, without a computer, the mine surveyor created the final visualized product the mine surveying plan, although this visualization did not involve the use of 3D technology. Now, the final product resulting from surveying, such as a point cloud, cannot be called visualized. However, to improve it, modern powerful software products can be used that allow converting this data into sufficiently accurate and visual 3D-scenes. Undoubtedly, the new progressive methods can improve the efficiency of field and cameral work when compiling graphic documentation, and therefore, they should be used instead of the methods already outdated. However, as studies have shown, classical methods cannot be completely abandoned and, if necessary, they can be used together, complementing each other.

For example, the use of an orthophotoplan is effective when solving the problems of cadastre and land surveying, since this reduces the time of work, increases the detail of the resulting document, hence, it is convenient and visual. The use of orthophotoplan for the territory of a quarry or other mining object is rather limited, since the range of tasks to be solved for it is rather small. By imposing contours on the orthophotoplan, some kind of visualization effect can be 
obtained, but solution of technical problems using such material does not provide sufficient accuracy. According to the current regulatory documents, contours on the slope on the mine surveying plan are necessary if the slope occupies a significant area in the plan, or has a complex relief and shape. The slope surface cannot be plotted graphically in any other way than marking characteristic points and contours.

The subject of research is the methods of visualizing the situation and relief on mine surveying plans and spheres of their application. The research is made using the example of deep iron ore quarries and other objects of mining enterprises, such as a quarry filled with waste rocks as a result of its reclamation, as shown in Figure 1.

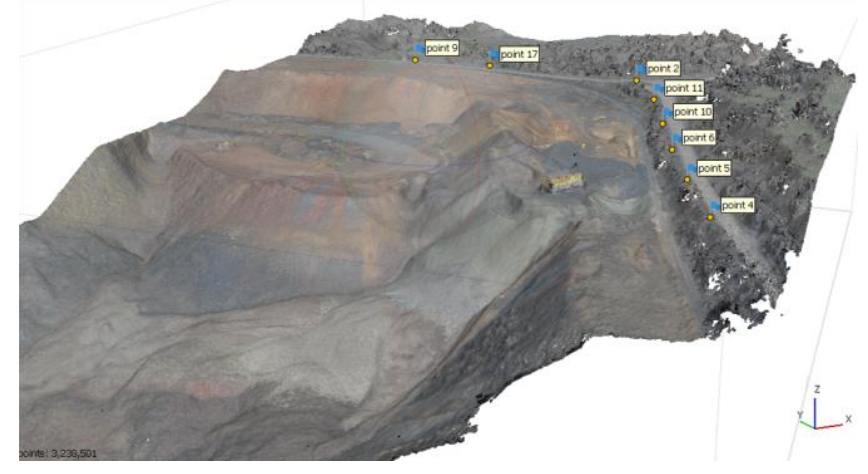

Figure 1. Research object

An object with a total area of 908 thousand $\mathrm{m}^{2}$ is studied, where the zone of changes is 15.3 thousand $\mathrm{m}^{2}$. A test surveying is made on this territory of 15.3 thousand $\mathrm{m}^{2}$ using the Ebee Sense Fly unmanned aerial vehicle.

Figure $2 \mathrm{a}$ shows a fragment of the mine surveying plan developed by the authors according to the classical method in compliance with the relevant requirements of instructions and manuals. Such a plan can be used to solve any problems of mine surveying service that have to be solved in the course of its activity. It can also be used by other services and specialists during the exploitation of a mineral deposit.

Typically, such a plan is created using a stereoscope by collecting manually various elements, such as upper and lower edges, quarry roads, electric power lines, and the like. Figure $2 b$ shows a fragment of the mine surveying plan, in the preparation of which the orthophotoplan is used as a mount, thereby increasing its visualization. The mine surveying plan with a mount is readable for specialists of different profiles, namely, economists, managers of various levels, employees of guarding structures, etc.

One of the urgent problems when surveying with the use of unmanned aerial vehicle for mine surveying support of mining enterprises is the impossibility of doing without a manual drawing of the situation. The developers of the UAV and software for it assumed the automation of all processes and minimal human intervention [27]. However, to solve many mine surveying tasks, the plan obtained as a result of such processing of a survey does not have the information necessary for this, although it is characterized by redundant data.

Figure 3a demonstrates a digital terrain model (DTM) with contours on the research object, constructed automatically. As can be seen, there is a lot of redundant unnecessary information on the plan, that is, such DTM has high detail (points generated every 0.1 meters), but low accuracy. (a)

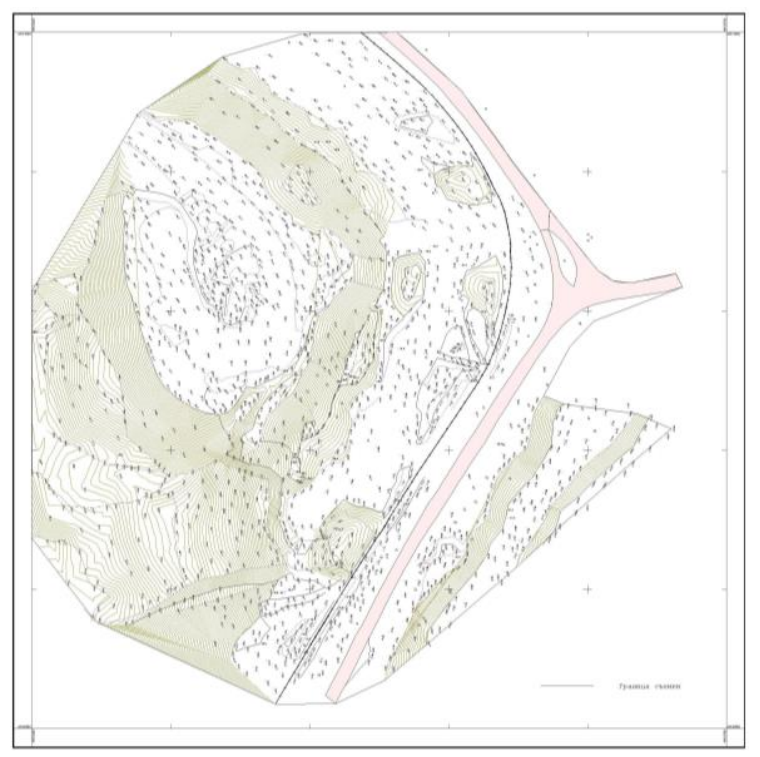

(b)

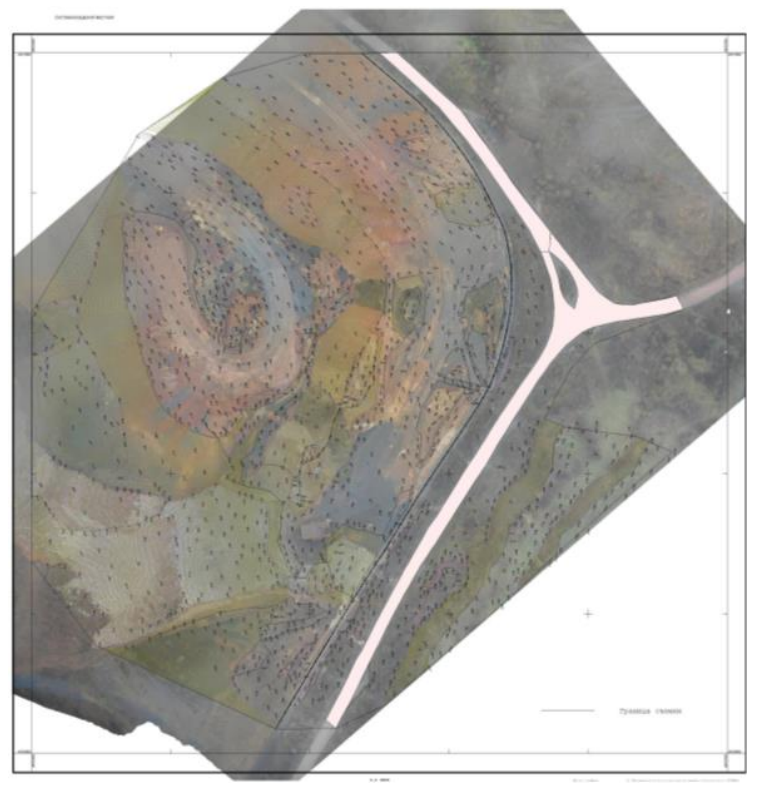

Figure 2. Fragment of a plan drawn up according to: (a) classical method; (b) using orthophotoplan

For example, forest ranges, an excavator and other volumetric objects are recognized by the program as surface elements. When compiling the presented fragments of plans and DTM, the authors used domestic software.

Figure $3 \mathrm{~b}$ presents a plan with contours created by structural lines and points, compiled manually. Obviously, this digital terrain model has much less redundant information and is higher by accuracy.

The calculation has been made of an error in determining the volume by the plan, which has redundant unnecessary information. The volume from the zero surface was calculated twice. In the first case, the classical mine surveying plan was used for calculations and the volume according to it amounted to $4398874.628 \mathrm{~m}^{3}$, and in the second case - the plan with redundant information was used, according to which the volume amounted to $4415142.797 \mathrm{~m}^{3}$. 
(a)

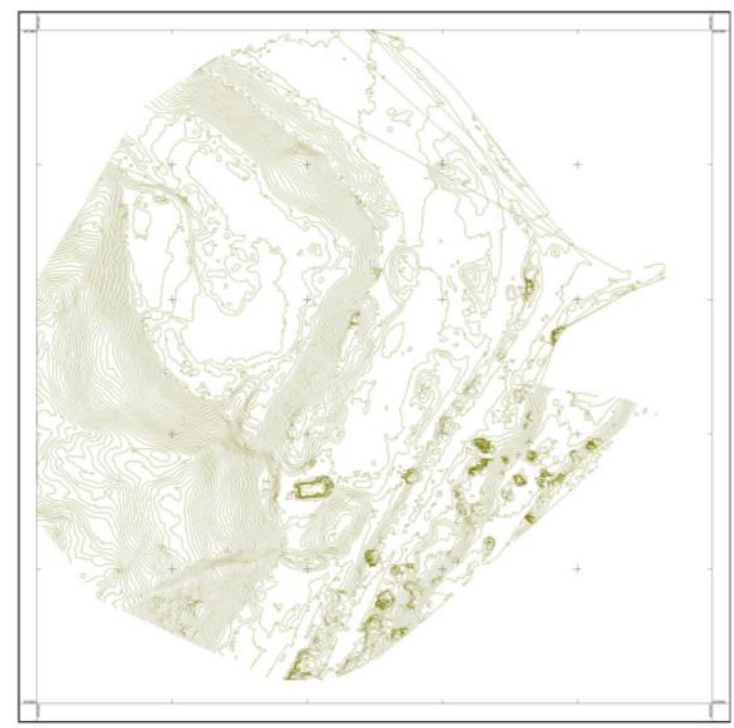

(b)

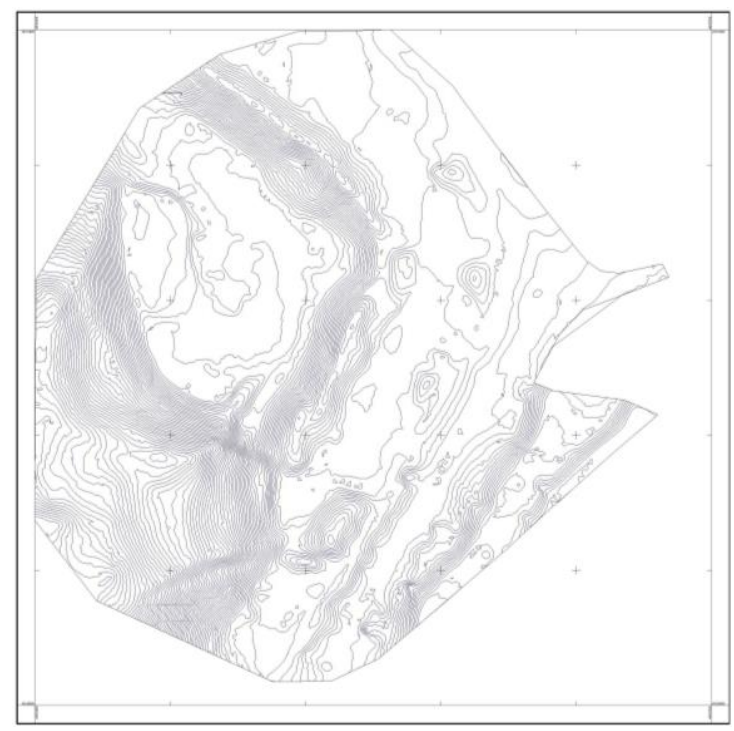

Figure 3. DTM, constructed automatically (a) and manually (b)

The area of the contour within which the volume was calculated is $153142 \mathrm{~m}^{2}$. The difference in volumes is $16268.169 \mathrm{~m}^{3}$, which corresponds to $0.37 \%$, and is an error due to accounting the marks of the tops of trees and shrubs in the studied dump area, which can be excluded during the subsequent surveying. From the example considered above, it can be concluded that to solve the problem of calculating the volume of mining operations, full automatic processing of the surveying results from the UAV can be used.

The camera was chosen on the basis of the data analysis results from more than 10 thousand images obtained with three short-focal and one long-focal lenses. Using the Agisoft Metashape Professional program, the results of assessing the image quality for lenses have been obtained: 1) Canon Lens EF $50 \mathrm{~mm} \mathrm{1:1/8} \mathrm{II;} \mathrm{2)} \mathrm{Canon} \mathrm{Lens} \mathrm{EF-S} 24 \mathrm{~mm}$ f/2.8STM; 3) MC-3M-5CA; 4) Canon EF 100-300 mm F5.6.

These studies led to the following conclusion. The highest image quality of the three short-focal lenses is provided by Canon Lens EF-S $24 \mathrm{~mm}$ f/2.8STM. It demonstrated consistently high image quality with a mean value of 0.73 and a median of 0.79 . Canon Lens EF $50 \mathrm{~mm} \mathrm{1:1/8} \mathrm{II} \mathrm{is}$ slightly inferior to it, and the MC-3M-5CA lens, even with the use of a focus confirmation chip, showed poor image quality. The Canon EF 100-300 mm F5.6 lens, chosen as a long-focal lens, is necessary for further research, with a mean value and median of 0.66 and 0.68 , respectively.

For the research, experimental surveyings have been made using two cameras Canon EOS1200D and Canon 350D. The cameras are equipped with different lenses. The Canon EOS1200D camera is equipped with a Canon Lens EF $50 \mathrm{~mm}$ 1:1/8 II with fixed focal distance, and the Canon 350D camera has a Canon Zoom Lens EF-S 18-55 mm 1:3.5-5.6 IS with variable focal distance. They have a differ-rent number of pixels: Canon EOS1200D - 18 million; Canon 350D - 8 million.

It is expedient to perform surveying with a lens with a fixed focal distance. The use of wide-angle lenses has a significant advantage - a larger coverage area, and thus minimal number of images. For example, when surveying the open pit flank with a camera with a lens of $50 \mathrm{~mm}$ focal distance, 7-9 images are obtained, while when surveying the same area with a camera with a lens of $24 \mathrm{~mm}$ focal distance, there are only 1-2. However, due to a large field-of-view angle, the pixel size is sacrificed, as well as significant geometric deformations of the lens - distortion. The number of images covering the open pit flank for the Canon EOS1200D camera with the Canon Lens EF $50 \mathrm{~mm} \mathrm{1:1.8} \mathrm{II} \mathrm{is} \mathrm{32,} \mathrm{and} \mathrm{for} \mathrm{the}$ Canon 350D camera with the Canon Zoom Lens EF-S 18$55 \mathrm{~mm} \mathrm{1:3.5-5.6} \mathrm{IS} \mathrm{-} 9$.

Table 1 shows the errors at the control points for the two cameras that are used in the research. The mine surveying plan accuracy is influenced not only by the method of its construction, but also by the accuracy of the output substantiation, which is used in this case [27]. Figure 4 shows the position of the control and check points and the values of errors on them. Errors along the $Z$ axis are depicted by a specific colour of the ellipse, and errors in plan - by the size of the ellipse.

Table 1. Coordinate errors on control points

\begin{tabular}{cccccccccccc}
\hline Label & $\Delta X, \mathrm{~cm}$ & $\Delta Y, \mathrm{~cm}$ & $\Delta Z, \mathrm{~cm}$ & Total, cm & Image, pix & Label & $\Delta X, \mathrm{~cm}$ & $\Delta Y, \mathrm{~cm}$ & $\Delta Z, \mathrm{~cm}$ & Total, cm & Image, pix \\
\hline \multicolumn{4}{c}{ Canon EOS1200D, } \\
\multicolumn{4}{c}{ Canon Lens EF 50 mm 1:1/8 II } & \multicolumn{5}{c}{ Canon 350D, } \\
\hline Point 1 & 3.4 & 0.74 & 7.24 & 7.92 & 2.484 & point 1 & 130.70 & 39.10 & 50.90 & 145.60 & 70.70 \\
\hline Point 2 & -8.67 & -0.63 & -2.66 & 9.09 & 1.066 & point 2 & 85.70 & 35.60 & 18.60 & 94.70 & 71.40 \\
\hline Point 3 & - & - & - & - & - & point 3 & - & 0 & - & 0 & 0 \\
\hline
\end{tabular}

The position of the control points is shown by a black dot, and check points - by a criss-cross. Obviously, it is not necessary to use cameras with wide-angle lenses for solving problems that require high accuracy, but for solving many problems of mine surveying support at a mining enterprise, when the fuzzy contours of the upper and lower edges are oriented and plotted on the plan sometimes with an accuracy of one meter, their use is rational. 
(a)

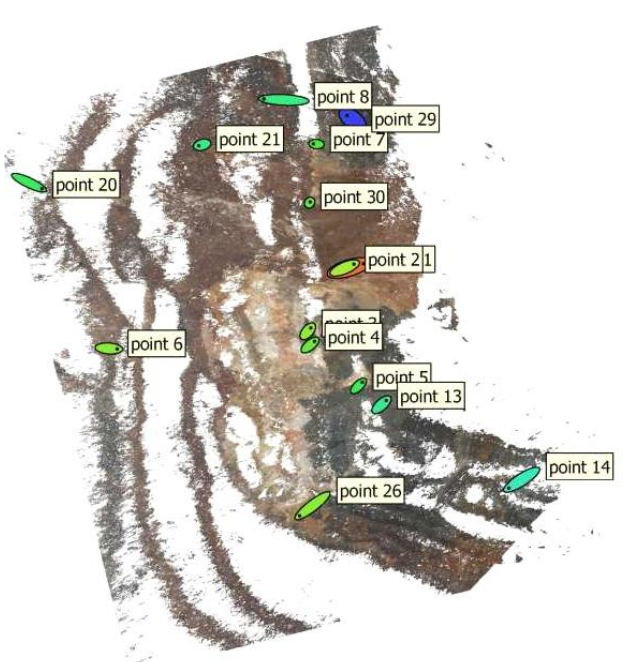

○ $60 \mathrm{~cm}$

O $48 \mathrm{~cm}$

○ $36 \mathrm{~cm}$

○ $24 \mathrm{~cm}$

○ $12 \mathrm{~cm}$

$\circ 0 \mathrm{~cm}$

$0-12 \mathrm{~cm}$

$0-24 \mathrm{~cm}$

$0-36 \mathrm{~cm}$

O $-48 \mathrm{~cm}$

$-60 \mathrm{~cm}$

$\underset{x 30}{ }$

- Control points

T Check points

(b)

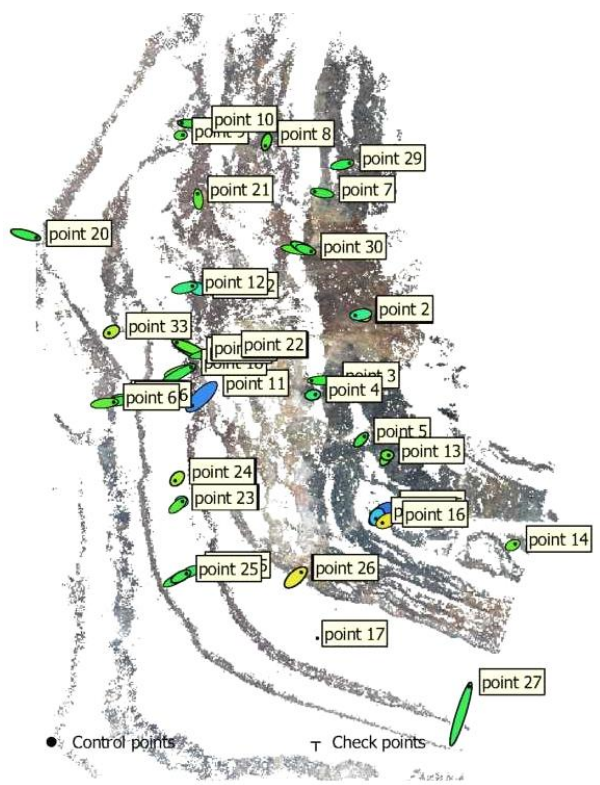

$25 \mathrm{~cm}$

O $20 \mathrm{~cm}$

O $15 \mathrm{~cm}$

O $10 \mathrm{~cm}$

○ $5 \mathrm{~cm}$

$\circ 0 \mathrm{~cm}$

○ $-5 \mathrm{~cm}$

$0-10 \mathrm{~cm}$

O $-15 \mathrm{~cm}$

O $-20 \mathrm{~cm}$

$-25 \mathrm{~cm}$

$\times 150$

$200 \mathrm{~m}$

Figure 4. Positions of control and check points when surveying with (a) a lens with $24 \mathrm{~mm}$ focal distance; (b) a lens with $50 \mathrm{~mm}$ focal distance

\section{Results and discussion}

Figure 5 graphically presents a comparative characteristic of the errors at the control points when using cameras, Canon EOS1200D and Canon 350D, respectively.

In Figure 5, the errors obtained by different cameras, are shown in different colours. Designing errors: when using an uncalibrated Canon 350D camera equipped with a Canon Zoom Lens EF-S 18-55 mm 1:3.5-5.6 IS, there are significantly more errors than when using a Canon EOS1200D camera with a Canon Lens EF $50 \mathrm{~mm} \mathrm{1:1/8} \mathrm{II.} \mathrm{One} \mathrm{major}$ source of errors is the influence of lens characteristics. It is known that this is not the only source of errors, though important one. The lenses research results are presented in the form of histograms (Fig. 6).

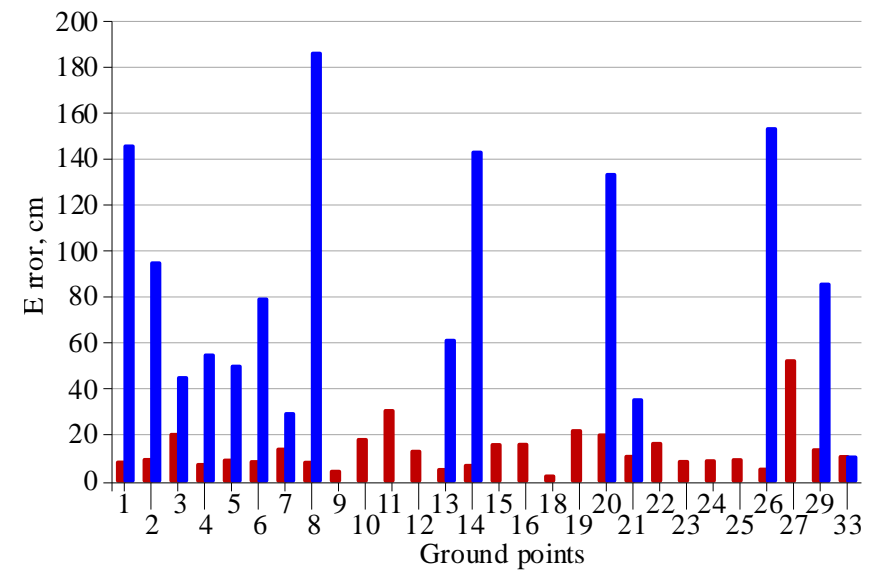

- Canon EOS 1200D, Canon Lens EF 50mm 1:1,8 II

-Canon EOS 350D,Canon Lens EF-S 24mm f/2,8 STM

Figure 5. Graphic display of error values at control points

(a)

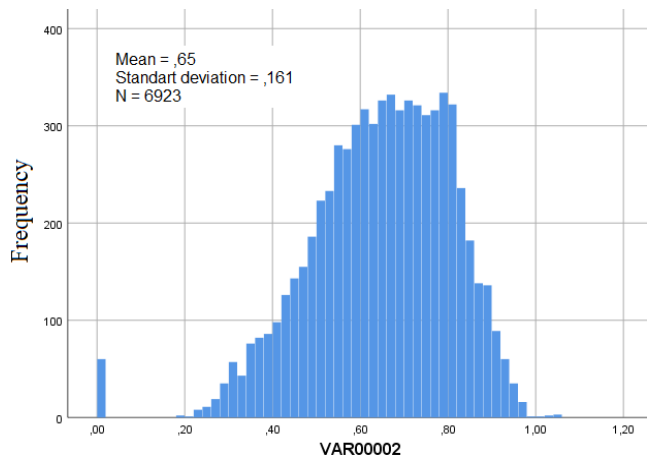

(b)

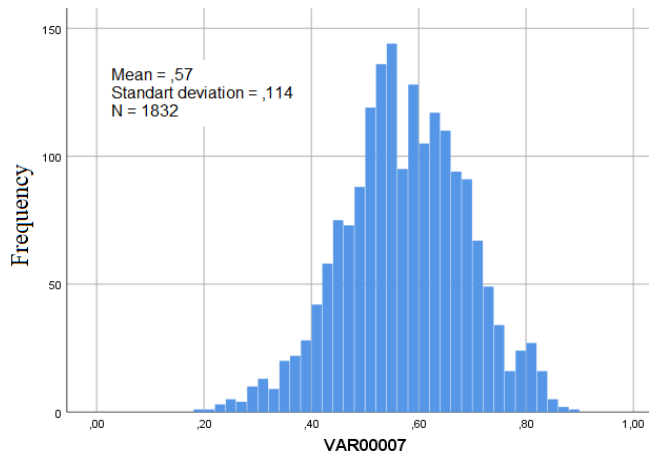

(c)

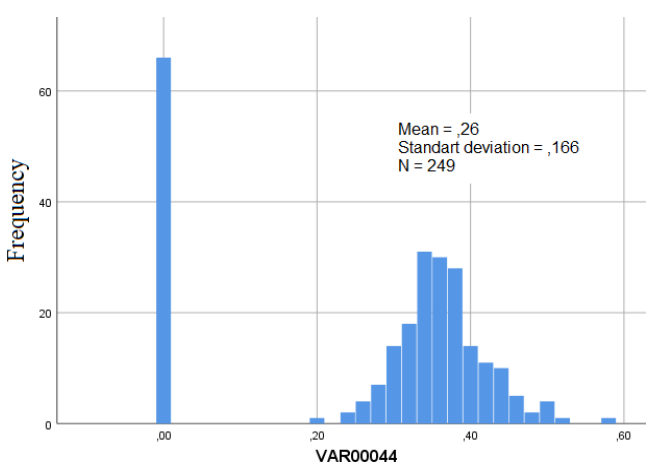

Figure 6. Quality histograms of the images made with lenses: (a) Canon Lens EF $50 \mathrm{~mm}$ 1:1/8 II; (b) Canon Lens EF-S 24 mm f/2.8 STM; (c) MC-3M-5CA 
From the data given in Table 1, it can be seen that when surveying with two different cameras for almost one physical moment (interval 3-5 minutes), a different number of control points is used. The number of pixels of the matrix is an important characteristic of the camera when surveying from long distances. Canon EOS350D with 8 million of pixels, released in 2005 , at that time had high quality parameters, but compared to the Canon 1200D with 18 million of pixels, released in production in 2014 , it significantly loses. When using the Canon 350D for surveying from long distances to the object, even contrasting contours are not recognized.

Figure 7 shows images of a railway track section obtained by two studied cameras. In the first picture, the left and right ends of the section are well recognized, that is, they are clear contours that can be taken as control points. In the second picture, the contour is hardly recognized. If in the first image the area highlighted in red occupies $0.21 \%$ of the image, then in the second it is only $0.07 \%$, which is 3 times less. Hence, the number of pixels of the camera matrix that covers this area is much less. As a result of using a wide-angle lens with a focal distance of $24 \mathrm{~mm}$, the coverage area is increased.

(a)

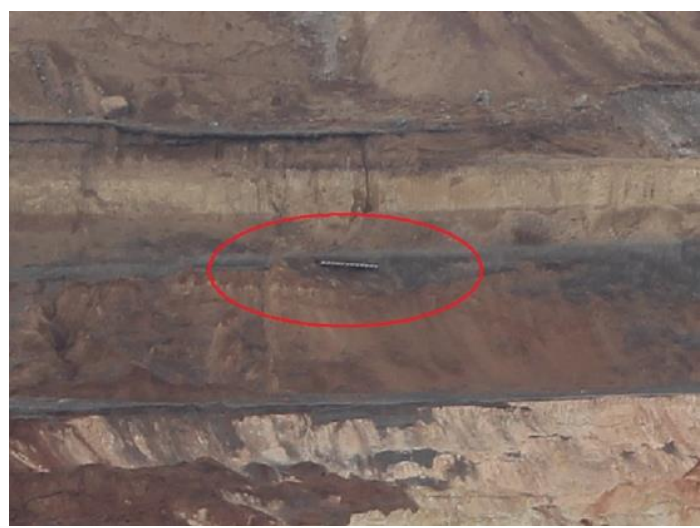

(b)

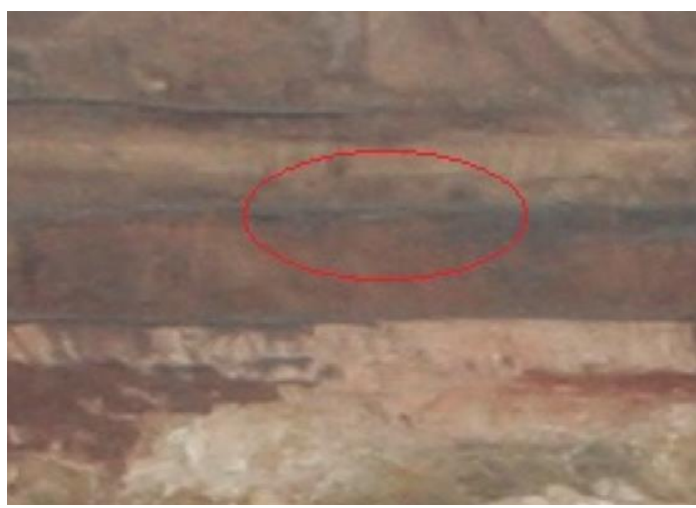

Figure 7. Image of a railway track section obtained with two lenses: (a) with $50 \mathrm{~mm}$ focal distance; (b) with $24 \mathrm{~mm}$ focal distance

It can be concluded that when using short-focal lenses, the number of images required to survey the studied object is significantly reduced, but the image quality is so low that processing is impossible in some cases. Using a lens with a fixed focal distance of $40 \mathrm{~mm}$, namely the Canon EF $40 \mathrm{~mm}$ f/2.8 STM, would increase the coverage area of an object in a single image practically without loss in image quality.
To study the dependence of the image quality on the number of pixels, two images are considered, one of which is obtained with a Canon EOS1200D camera, and the other with a Canon 350D camera. In this case, both images are made with the same lens - Canon Lens EF 50 mm 1:1/8 II (Fig.8).

(a)

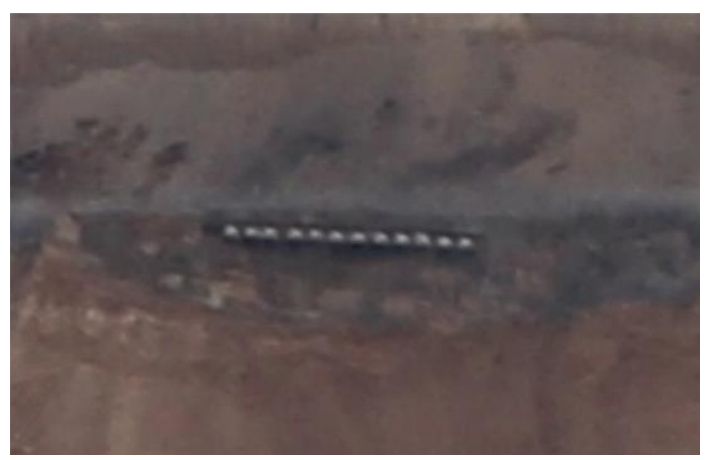

(b)

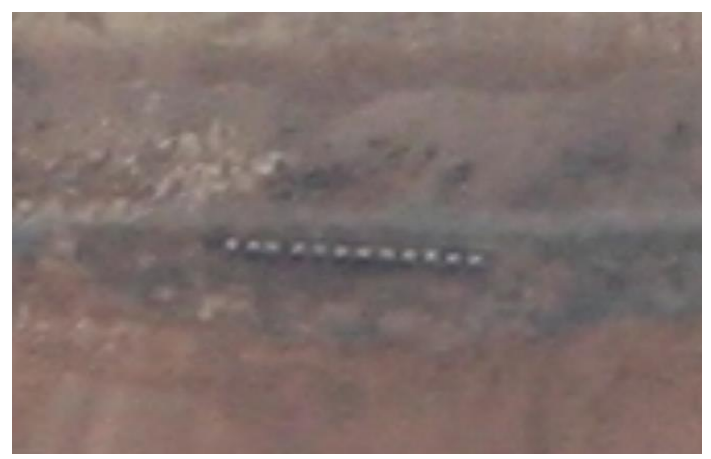

Figure 8. Images obtained by different cameras with the same lenses: (a) 18-megapixel camera; (b) 8-megapixel camera

Analyzing the quality of the images captured by 18megapixel and 8-megapixel cameras, it can be concluded that the difference between them is insignificant. However, in the first picture the image is clearer, and in this case a darkcolored railway track is recognized, while it is not recognized in the second picture. The images captured by 18-megapixel camera are more comfortable to process stereoscopically when manually collecting the situation. Therefore, when choosing a camera for surveying objects of mining enterprises, special attention should be focused on the selection and calibration of the lens, and less attention - to the matrix size.

Canon EOS1200D and Canon 350D cameras have cropped matrices with $K_{r}=1.62$. Mine workings should be surveyed using full-size matrices, but this is not possible today.

It can be concluded that the equipment of unmanned aerial vehicles with the most modern cameras with the maximum possible number of pixels is, in fact, a marketing ploy that contributes to the rise in equipment prices and is an important argument for purchasing a new UAV.

Figure 9 presents images of the slope section obtained from a distance of 650 meters by cameras with the number of megapixels 8, 18 and 24. The same Canon Lens EF $50 \mathrm{~mm} \mathrm{1:1/8} \mathrm{II} \mathrm{with} \mathrm{a} \mathrm{fixed} \mathrm{focal} \mathrm{distance} \mathrm{is} \mathrm{used} \mathrm{for} \mathrm{sur-}$ veying. The outlined and zoomed part of the image occupies only $0.11 \%$ of the image area. A significant difference in image quality is observed only for images captured by 8 and 18-megapixel cameras. 
(a)

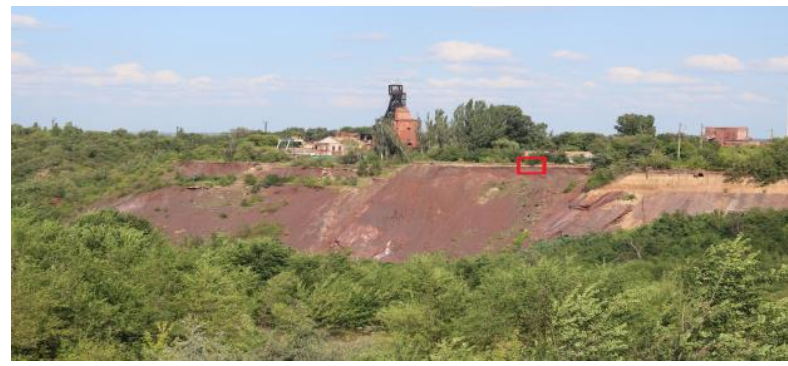

(b)

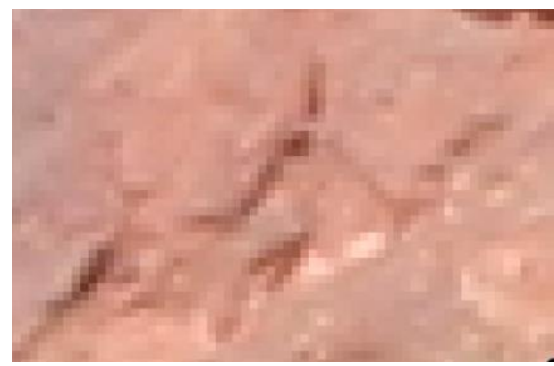

(e)

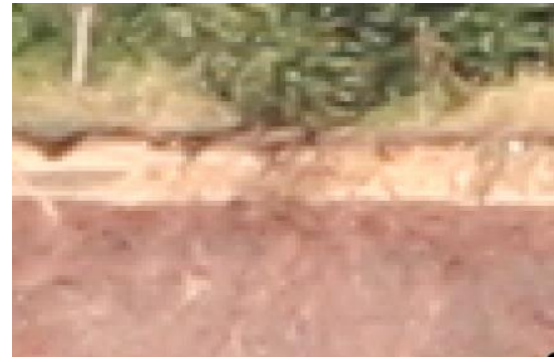

(c)

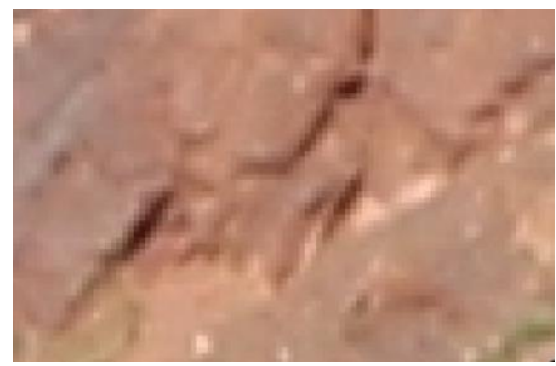

(f)

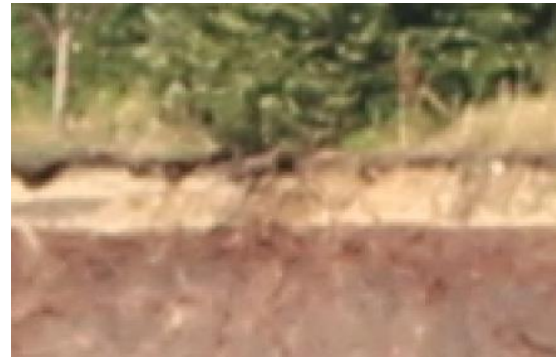

(d)

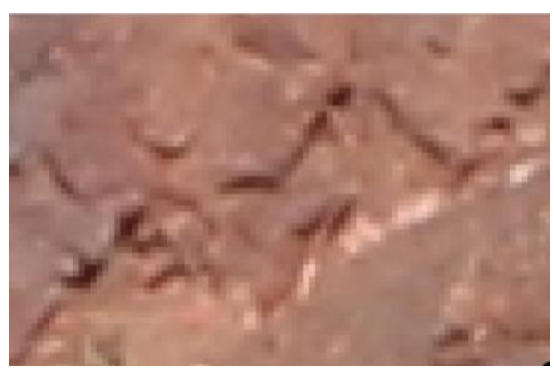

(g)

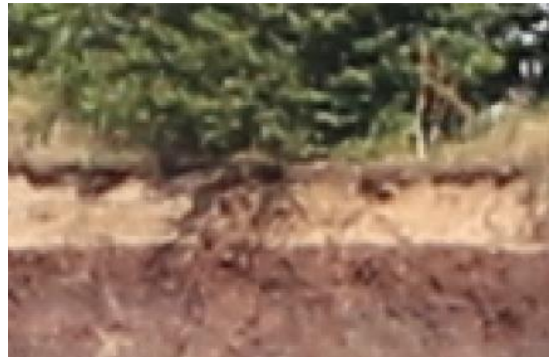

Figure 9. Images obtained by different cameras with the Canon Lens EF $50 \mathrm{~mm} \mathrm{1:1/8} \mathrm{II:} \mathrm{(a)} \mathrm{original} \mathrm{image;} \mathrm{(b),} \mathrm{(e)} \mathrm{fragments} \mathrm{of} \mathrm{the}$ image captured by 8-megapixel camera; (c), (f) fragments of the image captured by 18-megapixel camera; (d), (g) fragments of the image captured by 24-megapixel camera

Figure 9a shows the original image, Figures $9 \mathrm{~b}$ and $9 \mathrm{e}$ show fragments of the image captured by an 8-megapixel camera. Figures $9 \mathrm{c}$ and $9 \mathrm{f}$ present the fragments of the image captured by 18 -megapixel camera, and Figures $9 \mathrm{~d}$ and $9 \mathrm{~g}-$ fragments of the image captured by 24-megapixel camera.

\section{Conclusions}

As a research result, the most effective camera and lens for performing mine surveying have been selected, as well as the characteristics have been determined that they should have to obtain the necessary accuracy and completeness of data. Mine surveying service can use this data not only for drawing up a plan, but also for solving other tasks, for example, to monitor the deformations. An analysis of the quality of images obtained by cameras with different numbers of pixels and with different focal distance made it possible to determine their most important characteristics, which significantly influence on the accuracy of the data obtained from the images. Having analysed the accuracy of determining the object points coordinates, which are obtained from the surveying results, it has been revealed that it is greatly influenced by the accuracy of the output substantiation and the number of points. As a research result, the optimal distances to the surveyed objects have been determined depending on the type of work and the characteristics of the surveying equipment. The research has shown that when surveying from a distance of $600-700 \mathrm{~m}$ from the object, there is no significant difference between the images obtained by 18 - and 24megapixel cameras. This also refers to cameras set on drones. If to take into account that the flight altitude of the drone when surveying mine workings fluctuates between 200$300 \mathrm{~m}$, then 8- or 18-megapixel cameras are enough to get high-quality and clear images. It is known that the accuracy of determining markers (index marks), which are placed, as well as accuracy of processing depend on the images quality.

\section{Acknowledgements}

The authors express their gratitude to the PJSC "Central Iron Ore Enrichment Works" administration for the provided opportunity to conduct research at its facilities.

\section{References}

[1] Dolgikh, A.V. (2014). Application of neural networks to investigations into the earth surface mined by underground operations. Geomatica, (1), 92-96.

[2] Dolgikh, O.V. (2018). Use of capabilities of modern devices in investigating into slides on territories of mining enterprises. Kachestvo Mineralnogo Syria, 323-331.

[3] Fedorenko, P.I., Dolgikh, A.V., \& Dolgikh, L.V. (2018). Analysis of factors affecting the position of the benchmarks of the profile lines of 
the observation station. Visnyk Kryvorizkoho Tekhnichnoho Universytetu, (47), 55-59.

[4] Kalinichenko, V., Dolgikh, O., \& Dolgikh, L. (2019). Digital survey in studying open pit wall deformations. E3S Web of Conferences, (123), 01047. https://doi.org/10.1051/e3sconf/201912301047

[5] Kuznetsova, I.A., \& Tyulegenova, A.V. (2012). Using Earth remote sensing data to create digital topographical plans for quarries. Mining Journal of Kazakhstan, (6), 21-23.

[6] Pushchin, A.V. (2018). Assessment of the stability of spectral sensitivity of digital color cameras. Scientific and Technical Messenger of Information Technology, Mechanics and Optics, 18(3), 363-368.

[7] Arkhipov, P.O., Sidorkin, I.I., \& Tsukanov, M.O. (2018). Algorithmic model of technology to minimize distortions when stitching images taken from UAVs. High Availability Systems Radio Technology, 14(5).

[8] Wu, F., Wei, H., \& Wang, X. (2017). Correction of image radial distortion based on division model. Optical Engineering, 56(1), 013108. https://doi.org/10.1117/1.oe.56.1.013108

[9] Kunina, I.A., Gladilin, S.A., \& Nikolaev, D.P. (2016). Blind radial distortion compensation in a single image using fast Hough transform. Computer Optics, 40(3), 395-403. https://doi.org/10.18287/2412-61792016-40-3-395-403

[10] Instruction on surveillance of walls, slopes of benches and dumps at open-pits and development of measures to ensure their stability. (1971). Leningrad, Russia: VNIMI.

[11] Methodology instructions on surveillance of deformations of walls of and dumps, interpretation of the results and forecasts. (1987). Leningrad, Russia: VNIMI.

[12] Kalinichenko, V., Pysmennyi, S., Shvaher, N., \& Kalinichenko, O. (2018). Selective underground mining of complex structured ore bodies of Kryvyi Rih Iron Ore Basin. E3S Web of Conferences, (60), 00041 https://doi.org/10.1051/e3sconf/20186000041

[13] Stupnik, M.I., Kalinichenko, V.O., Kalinichenko, O.V., Muzika, I.O., Fed'ko, M.B., \& Pismennyi, S.V. (2015). The research of strain-stress state of magnetite quartzite deposit massif in the condition of mine "Gigant-Gliboka" of central iron ore enrichment works (CGOK). Metallurgical and Mining Industry, (7), 377-383.

[14] Stupnik, N., Kalinichenko, V., Pismennij, S., \& Kalinichenko, E. (2015). Features of underlying levels opening at "Arsellor Mittal Kryvyi Rih" underground mine. New Developments in Mining Engineering 2015: Theoretical and Practical Solutions of Mineral Resources Mining, 39-44. https://doi.org/10.1201/b19901-8

[15] Beregovoi, D. (2015). Potential analysis of image based methods for deformation monitoring, with special regard on the comparison of dif- ferent image processing software. Leoben, Austria: Montanuniversität Leoben, Department of Mineral Resources Engineering.

[16] Carvajal, F., Agüera, F., \& Pérez, M. (2012). Surveying a landslide in a road embankment using unmanned aerial vehicle photogrammetry. ISPRS - International Archives of the Photogrammetry, Remote Sensing and Spatial Information Sciences, (XXXVIII-1/C22), 201-206. https://doi.org/10.5194/isprsarchives-Xxxviii-1-c22-201-2011

[17] Peng, S.S. (1992). Surface subsidence engineering. Ann Arbor, United States: Society for Mining, Metallurgy, and Exploration.

[18] Pollefeys, M. Visual 3d modeling from images-tutorial notes: technical report. Chapel Hill, United State: University of North Carolina.

[19] Peterman, V. (2015). landslide activity monitoring with the help of unmanned aerial vehicle. ISPRS - International Archives of the Photogrammetry, Remote Sensing and Spatial Information Sciences, (XL1/W4), 215-218. https://doi.org/10.5194/isprsarchives-Xl-1-w4-215-2015

[20] Suh, J., \& Choi, Y. (2017). Mapping hazardous mining-induced sinkhole subsidence using unmanned aerial vehicle (drone) photogrammetry. Environmental Earth Sciences, 76(4), 144-155. https://doi.org/10.1007/s12665-017-6458-3

[21] Padró, J.-C., Carabassa, V., Balagué, J., Brotons, L., Alcañiz, J.M., \& Pons, X. (2019). Monitoring opencast mine restorations using Unmanned Aerial System (UAS) imagery. Science of The Total Environment, (657), 1602-1614. https://doi.org/10.1016/j.scitotenv.2018.12.156

[22] Xiang, J., Chen, J., Sofia, G., Tian, Y., \& Tarolli, P. (2018). Open-pit mine geomorphic changes analysis using multi-temporal UAV survey. Environmental Earth Sciences, 77(6), 220-237. https://doi.org/10.1007/s12665018-7383-9

[23] Rossi, P., Mancini, F., Dubbini, M., Mazzone, F., \& Capra, A. (2017). Combining nadir and oblique UAV imagery to reconstruct quarry topography: methodology and feasibility analysis. European Journal of Remote Sensing, 50(1), 211-221. https://doi.org/10.1080/22797254.2017.1313097

[24] Gonzales, R., \& Woods, R. (2012). Tsifrovaya obrabotka izobrazheniy. Moskva, Rossiya: Tekhnosfera.

[25] Khlebnikova, T.A., \& Opritova, O.A. (2017). Experimental research of modern software products for the simulation of geospace on UAV materials. Visnyk SGUGIT, 22(1), 119-131.

[26] Kršák, B., Blišt’an, P., Pauliková, A., Puškárová, P., Kovanič, L., Palková, J., \& Zelizňaková, V. (2016). Use of low-cost UAV photogrammetry to analyze the accuracy of a digital elevation model in a case study. Measurement, (91), 276-287. https://doi.org/10.1016/j.measurement.2016.05.028

[27] Johansen, K., Erskine, P.D., \& McCabe, M.F. (2019). Using unmanned aerial vehicles to assess the rehabilitation performance of open cut coal mines. Journal of Cleaner Production, (209), 819-833. https://doi.org/10.1016/i.jclepro.2018.10.287

\section{Вибір камери для маркшейдерської зйомки об'єктів гірничорудних підприсмств за допомогою безпілотних літальних апаратів}

\section{В. Калініченко, О. Долгіх, Л. Долгіх, С. Письменний}

Мета. Вибір ефективного методу виконання маркшейдерської зйомки об'єктів гірничодобувних підприємств на основі використання сучасних технологій для виконання польових і камеральних робіт на кар'єрах, відвалах, ділянках зон обвалень тощо. Одним із пріоритетів при створенні графічного матеріалу у вигляді маркшейдерського плану або іншої гірничо-графічної документації $є$ суворе дотримання вимог, які пред’являються до якості документів, що складаються.

Методика. Аналіз експериментальних даних, отриманих у результаті виконаних знімальних робіт: території шахти, де відбулося обвалення земної поверхні; борту кар'єру, де спостерігається зсув; території кар'єру, де проводиться рекультивація. Зйомки з землі та 3 повітря виконані цифровими камерами з різними технічними характеристиками матриць і об'єктивів. При зйомці з землі використовувалося фотографування зі штатива, а при зйомці з повітря носієм камери був безпілотний літальний апарат (БПЛА).

Результати. Отримані якісні характеристики зображень, які були створені різними камерами в різних знімальних умовах. Дослідження показали, що при зйомці з відстані 600-700 м від об'єкта, істотної різниці між зображеннями, отриманими 18-ти й 24мегапіксельними камерами, немає. Це стосується й камер, які встановлюються на дронах. Отримана залежність точності визначення координат точок по цифрових знімках від якісних характеристик знімальної апаратури, яка використовується при фотографуванні з землі або встановлюється на БПЛА.

Наукова новизна. Виявлено взаємозв'язок між точністю обмірюваних даних по знімках, отриманих для досліджуваного об'єкта, і метричними характеристиками цифрових камер та об'єктивів, які використовувалися для їх одержання.

Практична значимість. Розроблена методика виконання зйомок кар'єрів, відвалів та інших об'єктів гірничорудних підприємств із найбільшою їх ефективністю, що є корисним у гірництві для проектування, моніторингу та прогнозування. Рекомендується подальші дослідження вести у напрямку вдосконалення існуючих на сьогодні методів виконання наземного й повітряного фотографування кар'єрів та інших об'єктів гірничорудних підприємств.

Ключові слова: зображення, зона обвалення, камера, об'єктив, матриия, гірничорудний об'єкт 


\section{Выбор камеры для маркшейдерской съемки объектов горно-рудных предприятий с помощью беспилотных летальных аппаратов}

\section{В. Калиниченко, А. Долгих, Л. Долгих, С. Письменный}

Цель. Выбор эффективного метода выполнения маркшейдерской съемки горнодобывающих предприятий на основе использования современных технологий для выполнения полевых и камеральных работ на карьерах, отвалах, участках зон обрушений и тому подобное. Одним из приоритетов при создании графического материала в виде маркшейдерского плана или другой горнографической документации является строгое соблюдение требований, предъявляемых к качеству составляемых документов.

Методика. Анализ экспериментальных данных, полученных в результате выполненных съемочных работ: территории шахты, где произошло обрушение земной поверхности; борта карьера, где наблюдается смещение; территории карьера, где проводится рекультивация. Съемки с земли и с воздуха выполнены цифровыми камерами с различными техническими характеристиками матриц и объективов. При съемке с земли использовалось фотографирование со штатива, а при съемке с воздуха носителем камеры был беспилотный летательный аппарат (БПЛА).

Результаты. Полученные качественные характеристики изображений, которые были созданы различными камерами в различных съемочных условиях. Исследования показали, что при съемке с расстояния 600-700 м от объекта, существенной разницы между изображениями, полученными 18 -ти и 24-мегапиксельными камерами, нет. Это касается и камер, которые устанавливаются на дронах. Полученная зависимость точности определения координат точек по цифровым снимкам от качественных характеристик съемочной аппаратуры, которая используется при фотографировании с земли или устанавливается на БПЛА.

Научная новизна. Выявлена взаимосвязь между точностью измеренных данных по снимкам, полученным для исследуемого объекта, и метрическими характеристиками цифровых камер и объективов, которые использовались для их получения.

Практическая значимость. Разработана методика выполнения съемок карьеров, отвалов и других объектов горнорудных предприятий с наибольшей их эффективностью, что является полезным в горном деле для проектирования, мониторинга и прогнозирования. Рекомендуется дальнейшие исследования вести в направлении совершенствования существующих на сегодня методов выполнения наземного и воздушного фотографирования карьеров и других объектов горнорудных предприятий.

Ключевые слова: изображение, зона обрушения, камера, объектив, матрица, горнорудный объект

\section{Article info}

Received: 25 October 2019

Accepted: 28 October 2020

Available online: 7 December 2020 